\title{
Nonferrous Alloy Progress in 1921
}

\author{
By H. W. Gillett
}

U. S. Bureau of Mines, Sibley Colligg, Corneli University, Ithaca, N. Y.

$\mathbf{T}$

THE YEAR 1921 was one of business depression in which the nonferrous metal industry was hard hit. Prices of nonferrous metals were low, and production and consumption were at a minimum. Such conditions do not make for rapid commercial progress. In the general retrenchment, research laboratories in this field had to let many workers go, so that the scientific output fell off somewhat in quantity, though not in quality.

\section{Light Aluminium Alloys}

The light aluminium alloys received much attention. Cast alloys of the general type of $85 \mathrm{Al}: 15 \mathrm{Si}$ began to be tried out commercially, one automobile firm trying out one hundred crank-cases for an 8-cylinder car, and smaller castings of this alloy being used by various firms. This alloy bids fair to rival and perhaps to supplant the long-established No. 12 alloy of $92 \mathrm{Al}: 8 \mathrm{Cu}$, as it has a lower specific gravity, a higher tensile strength, and a decidedly greater ductility. In the foundry it appears to behave as well as No. 12 , though it requires some variation of foundry practice. If service tests bear out the improved physical properties shown by laboratory tests, we may expect quantity production and use of the new alloy to follow slowly.

In that case, the interesting problem will arise of the direct production of Al-Si alloys from lower grade ores, possibly from clay. At least some simplification of the process of purification of bauxite might become possible, perhaps resulting in a lowering of the cost of production of this alloy and its more extended use. Wrought alloys of the Duralumin type (e.g., $96.5 \mathrm{Al}, 3 \mathrm{Cu}, 0.5 \mathrm{Mg}$ ) have been the subject of a good deal of work which has been timely because of the tragedy of the ZR2, which was ascribed to failure of Duralumin. Merica and his co-workers at the Bureau of Standards published several papers dealing with Duralumin.

Jeffries and Archer, in an epoch-making discussion of the theory of hardening by slip-interference, considered the mechanism of the hardening of Duralumin as previously suggested in less detail by Merica, tied it in with the mechanism of the hardening of steel, and gave the metallurgical world a well-rounded theory, which, in conjunction with X-ray crystal analysis, gives us a basis for a more plausible answer to the riddle of "What is martensite in steel?" than we have had before, as well as showing the basic requirements that the equilibrium diagram of any alloy must meet in order that the alloy may respond to heat treatment.

Merica and Jeffries and Archer ascribed the hardening of Duralumin to the precipitation of the compound $\mathrm{CuAl}_{2}$. British investigators at the National Physical Laboratory, however, produce strong evidence that the hardening agent is another compound, $\mathrm{Mg}_{2} \mathrm{Si}$. It appears that both compounds play a role but that of the $\mathrm{Mg}_{2} \mathrm{Si}$ is predominant. If this is true, the discovery and development of Duralumin has been due to the fact that the commercial aluminium has in the past contained as an impurity the 0.25 to 0.35 per cent Si that is required to form $\mathrm{Mg}_{2} \mathrm{Si}$ in sufficient quantity to give a properly hardening Duralumin. The Aluminum Company of America has recently produced small amounts of aluminium of extreme purity and is working on the question of the hardening agents in Duralumin and of the effect of silicon. The purity of the aluminium available will allow them to carry the study to lower silicon contents than has hitherto been possible.

The National Physical Laboratory of England has brought out a modified Duralumin which they designate as " $\mathrm{Y}$ " alloy, which contains a little more $\mathrm{Cu}$ than the usual Duralumin and 2 per cent $\mathrm{Ni}$ also, the aluminium content being correspondingly decreased. This alloy is claimed to be the equal of Duralumin on all usual tests and to surpass it in resistance to repeated stress at $150^{\circ} \mathrm{C}$. It is described in detail in the Eleventh Report of the (British) Alloys Research Committee, which covers also a good deal of work on ternary aluminium alloys of the type containing about 3 per cent $\mathrm{Cu}$ and 20 to 25 per cent $\mathrm{Zn}$, with or without a little $\mathrm{Mg}$ and $\mathrm{Mn}$ in the wrong condition. These alloys, in castings, give the highest ratio of tensile strength to density of known cast aluminium alloys.

Rolling these alloys was a task requiring much patience but with suitable precautions it can be done, and material of 90,000 lbs. tensile strength per sq. in. can be produced. Another British investigation of interest was that of Carpenter and Elam on "Recrystallization of Aluminium Sheet."

Besides the work of Jeffries and Archer on the theory of hardening, they have discussed the question of grain size (a problem that has also received attention from a number of British investigators). Other contributions from the research staff of the Aluminum Company of America have dealt with the density of molten aluminium and $\mathrm{Al}-\mathrm{Cu}$ alloys at various temperatures, and with the heat treatment of castings.

Anderson, of the Bureau of Mines, has continued his work on practical problems relating to the preparation of aluminium alloys, dealing with cracking of castings in the foundry-gas atmospheres in aluminium-melting furnaces, iron-pot furnace practice, etc.

The use of aluminium alloy pistons in automobile engines appears to be progressing slowly. Some cars that previously used them have gone back to cast iron, while other cars have started to use them. As a result of improved design, recent aluminium pistons appear to be giving better results than earlier ones. Magnesium alloy pistons are being tried out, but the situation on Dowmetal, electron alloy, and similar alloys of a magnesium base seems to be one of general interest but little actual use as yet.

\section{Heavy Aluminium Alloys}

Of heavy alloys into which aluminium enters, aluminium bronze is the most important. Blue discussed the heat treatment of this alloy and pointed out that he had found the alloy unreliable because of the uncertainty of getting the same results twice and the difficulty in commercial production of getting the physical properties claimed for it on the basis of laboratory tests. This drew emphatic replies from producers of the alloy, but Blue countered by showing that his arguments were based on tests of alloys produced and heattreated by his critics themselves. A translation from the French of Grard's book on aluminium and its alloys has been published, which deals with the heat treatment of aluminium 
bronze, as well as exhaustively discussing aluminium and its light alloys.

\section{Brass AND Bronze}

Some attention has been paid, especially by French workers, to heat treatment of brasses and bronzes.

The research department of the Woolwich (England) Arsenal has published in the Journal of the British Institute of Metals three important papers, one by Genders on "The Extrusion Defect," which, with its discussion, covers many interesting points of the general subject of extrusion of metals, and one by the same author on "Casting Brass Ingots." The other, by Moore and co-workers on "Season Cracking of Brass," is extensive and has aroused much comment.

Corrosion of brass and Muntz metal has been dealt with by Rawdon of the Bureau of Standards. British investigators continued work on corrosion of condenser tubes. Another British investigation of scientific interest is that of Haughton on the copper-tin equilibrium diagram.

The American Brass Company has given a very fine paper on "Grain Growth in Alpha Brass." This firm has also made noteworthy application of spectroscopic analysis to routine laboratory work. The Scovill Manufacturing Company presented in This JourNal a method for electrolytic determination of very small amounts of lead.

The General Electric Company put out its new bearing metal, "Genelite," made by mixing oxides of copper, tin, etc., with an excess of graphite, reducing and compressing, giving an alloy carrying graphite mixed all through the material and hence having self-lubricating properties. The material is probably not applicable to a very wide field, but will fit in well for some uses.

The Anaconda Copper Mining Company, producers of copper and zinc, has taken over the American Brass Company, the largest producer of brass.

The competition of aluminium and nickel alloys, more recently rolled and extruded zinc, and still more recently of the new stainless iron (low carbon steel with around 15 per cent chromium) has threatened to cut into the fields heretofore served primarily by copper, brass, and bronze. The producers of copper and its alloys have therefore formed the Copper and Brass Research Association, whose function is to combat this encroachment and to develop new fields for the copper alloys. The organization does not cover the field that its name implies to a chemist or metallurgist, as it deals so far only with commercial research," $i$.e., propaganda and advertising (on a sane and reasonable basis), and not with chemical, physical, and metallurgical research. The field proposed by the National Research Council, which was to be covered by the Alloys Research Association but which materialized only in a limited information service on alloys, is still unfilled. The British Nonferrous Metals Research Association, with headquarters in Birmingham, appears to be getting a good start.

Notwithstanding the depression of 1921, the various brass rolling mills which had previously laid down plans for extensive installations of electric furnaces, went ahead with the installations, which is pretty good proof that electric brass melting is expected to continue to show lower melting costs than fuel-fired furnaces in the more normal times ahead, as well as under the conditions during and just after the war. Electric melting of brass and bronze has had a very rapid growth. There are to-day more electric brass furnaces installed in the United States than electric steel furnaces. While the average electric brass furnace is smaller than the average electric steel furnace, the percentage of electrically melted brass, in comparison with the total annual output, is greater than that of electrically melted steel.

\section{NICKEL}

Pure nickel and such alloys as Monel metal continue to find increasing application. Madsen has described before the American Electrochemical Society notable advances in the production of ductile electrolytic nickel, and Merica, of the International Nickel Company, has published a collection of data on the properties of nickel and its alloys.

Guillet, the French metallurgist, has discussed in Chemical and Metallurgical Engineering the replacing powers of various elements for zine in brass. An alloy of about $46 \mathrm{Cu}: 10 \mathrm{Ni}$ : $44 \mathrm{Zn}$ is of particular promise.

Foundrymen in this country were forced to use up a good deal of cupro nickel, shell-band scrap containing a little nickel, in recent years, and much of this went into alloys as if it were pure copper, giving alloys with small amounts of nickel. The generally satisfactory results have raised the question whether intentional additions of nickel may not be quite generally useful in copper alloys, since it forms a solid solution with copper that is stronger than copper, just as it forms a solid solution with iron and strengthens the ferrite, so that one may increase the strength of almost any steel by addition of suitable amounts of nickel.

The producers of nickel are naturally interested in this, and developments on this line may be looked for in the future.

\section{Cobalt}

One interesting development in connection with the cobaltchromium cutting alloy, stellite, is that the producers are making commercial inspection of stellite tools by the X-rays, to detect blowholes and other defects in the cast tools. The application of X-ray examination to metals is being carried farther than in the past and still further improvements are expected to be attained in the near future.

\section{ZINC}

Marked advances have been made in the application of rolled and extruded zinc to industrial use. Its cheapness and resistance to atmospheric corrosion make it useful for a multitude of uses. A paper by Mathewson of Yale and coworkers of the New Jersey Zinc Company in the Transactions of the American Institute of Mining and Metallurgical Engineers gives great detail on the properties and applicability of the material. One by Ingall in the Transactions of the British Institute of Metals on "Mechanical Properties and Microstructure of Rolled Zinc" supplements the American paper.

\section{GeneraL}

Steady progress is being made in fields that touch the interests of the chemist and metallurgist working on nonferrous alloys. Refinements and more speedy methods in chemical analysis, improvements in methods of physical testing, more knowledge of endurance testing, advances in metallography, etching practice, and photomicroscopy apply to the nonferrous as well as to the ferrous field.

Theoretical problems in atomic and crystal structure and arrangement, the study of space lattices by the $\mathrm{X}$-ray spectrometer, grain growth and recrystallization, the study of colloids and the application of colloid chemistry to metals and alloys bear on both ferrous and nonferrous alloys, and to discuss them here would take us outside the scope of this review.

It is interesting to note that some of the advocates of the "amorphous cement" theory appear to be modifying their views somewhat, especially in regard to cast metals, and opposition to the theory is beginning to be expressed as vigorously as is its propagation and defense. This will incite the collection of more experimental facts and more rig- 